\title{
Economic Impact of MAB Microfinance Program on Borrowers Household: Evidence from Rural Area of Bangladesh
}

\author{
Shamsuddin Ahamad*, Rosni Bakar, Zulkarnain Lubis \\ School of Business Innovation and Technopreneurship, University Malaysia Perlis (UniMAP), Perlis, Malaysia \\ Email Address: \\ shamsuddin.unimap@gmail.com (S. Ahamad),rosnibakar@gmail.com (R. Bakar), hzulkarnain@unimap.edu.my (Z. Lubis) \\ ${ }^{*}$ Corresponding author
}

\section{To cite this article:}

Shamsuddin Ahamad, Rosni Bakar, Zulkarnain Lubis. Economic Impact of MAB Microfinance Program on Borrowers Household: Evidence from Rural Area of Bangladesh. International Journal of Economics, Finance and Management Sciences.

Vol. 4, No. 5, 2016, pp. 298-302. doi: 10.11648/j.ijefm.20160405.20

Received: September 8, 2016; Accepted: September 21, 2016; Published: October 17, 2016

\begin{abstract}
Bangladesh is a pioneer and home of conceptualizing microfinance program. It has taken so many programs to reduce poverty and bring about socio-economic changes in the rural community. Since 1993, Muslim Aid UK, Bangladesh (MAB) is working with poor vulnerable people to improve their socioeconomic status through delivering interest-free microfinance in Bangladesh. This study is, therefore, aims to examine the economic impact of MAB microfinance program on borrowers' household income and consumption expenditure. Towards the achievement of its objectives, this study used descriptive and statistical techniques. To assess the impacts, primary data were collected from 95 borrowers from Chittagong district of Bangladesh. The simple random sampling method was followed to select the borrowers'. Multiple Linear Regression model were used to analyze the data. The findings revealed that MAB borrower's income and consumption expenditure increased after receiving the microfinance loan. Based on the results, the findings also revealed that amount of loan, loan sufficiency and religiosity had the most significant effect on income. In case of consumption expenditure, the amount of loan, tenure and loan sufficiency shown the significant effect.
\end{abstract}

Keywords: Impact, Microfinance, Income, Consumption Expenditure, Bangladesh

\section{Introduction}

Microfinance is an economic development approach that involves providing financial services, through institutions, to low-income clients, where the market fails to provide appropriate services. According to [1], microfinance is "The provision of small loans to help the poor and their families engage in production activities or develop microenterprises." The services provided by the Microfinance Institutions (MFIs) include credit saving and insurance services. Several microfinance institutions also provide social intermediation services such as training and education, organizational support, health and skills in line with their development objectives.

Though, the microfinance came as a revolutionary approach to eradicating poverty in the poor society but it is still insufficient in many aspects to reduce the overall poverty level in Bangladesh [2]. The population of Bangladesh living the poverty line stands at 31.5 percent in 2010 [3]. According to [4], $40 \%$ of the populations are poor in terms of income poverty. Therefore, evidence shows that conventional MFIs do not fulfill the demand for the microfinance and their interest rates are very high $[2,5]$.

Among more than seven hundred microfinance institutions at present working in Bangladesh [6], the UK-based NGO "Muslim Aid Bangladesh (MAB)" is the first microfinance program in Bangladesh which is working for the poor people to reduce the poverty by small and micro investment without charging interest [7]. Though more than seven hundred microfinance institutions are working in the country with a view to alleviating poverty but poor are still in the vicious circle of poverty and they have a little hope of getting out from poverty.

In such situation, it is more important to understand how Interest-free microfinance affects the progress of towards income and expenditure on consumption of the poor 
borrowers. Also, there is a lack of study on the interest-free microfinance institutions impacts on borrowers' improvement, particularly on the first interest-free microfinance institute Muslim Aid Bangladesh (MAB).

To address this problem, the research sets the objective to explore the views of borrowers towards the interest-free microfinance program in order to evaluate the impact of the program. It focuses on the impact of the borrowers' monthly income and consumption expenditure through income generating activities and identifies the factors related to the income and expenditure. It showed that MAB borrower's income and consumption expenditure increased after receiving the microfinance loan and had a significant effect.

\section{Literature Review}

Income and consumption expenditure are the most important socioeconomic indicators for the improvement of poor borrowers'. Literature shows that Interest-free microfinance is effective in raising income, consumption expenditure as well as reducing poverty from the society. An impact study on Baitul Maal wat Tamwil (BMT) in Indonesia, [8] found that BMT financing is effective in increase their income after receiving BMT financing. [9] found from Sri Lanka studies on Islamic Relief microfinance project that beneficiaries have generated incomes with new projects after receiving microfinance and increased their income. The authors also found that they are spending their income for purchasing food for their family.

[10] conducted a study to identify the effectiveness of the Amanah Ikhtiar Malaysia (AIM) microfinance program in reducing poverty among low-income households in rural areas in Malaysia. The results of studies revealed that income of AIM members increased after they joined AIM microfinance program. [11], [12] and [13] also conducted their study to examine the performance of Malaysian interestfree microfinance, Amanah Ikhtiar Malaysia (AIM) on household's income and expenditure. The authors also found that AIM microfinance program has a positive impact on borrowers' household income and expenditure. AIM has been successful to improve the income and expenditure level of their borrowers.

[14] studied the impact of microfinance clients of Rural Development Scheme (RDS) of Islami Bank Bangladesh Ltd. The authors found that household income significantly increased due to the influence of invested money. The authors also found that micro- investment program had a significant and positive contribution to the household's food expenditures and total expenditures.

[15], [16] and [17] also studied the impact on same countries and same IMFIs. The authors found that RDS microfinance borrowers have a better record of using the loan for income generating activities. Their research revealed that IMFIs' funds have been successful in increasing the income through income generating activities by the beneficiaries.

[18] study argued that the interest-free microfinance project, JAPEM of Brunei is highly effective in increasing the borrowers' number of business assets but the institution is not effective in terms of increasing the borrowers' income. Therefore, [19] from Indonesia and [20] from India argued that interest-free microfinance is an effective tool to improve income and expenditure capacity through income generating activities. [21] and [22] found that Islamic Relief Pakistan microfinance programs have been able to increase the borrower's income and also found a positive significant impact in terms of increasing their family expenditures. Results of the econometric models showed that household income and expenditure increased significantly due to the influence of the availability of micro-finance.

On the other hand, the literature showed that microfinance borrowers' income and expenditure are affected by some factors. Many researchers such as [13], [14], [17], [18] [23], [24], used many factors such as amount of loan, training etc. Thus, this study considered these factors as the independent variables.

Religiosity is an important factor for the improvement of borrowers of Interest-free microfinance. Researchers argued that religiosity can act as a collateral. It is also a most important agenda of interest-free microfinance institutions. As they use Islamic ethics in their objectives, so it should see the relationship between borrowers' religiosity and their income and expenditure. Thus, this study considered this factor as the independent variable. Therefore, very few studies used tenure and loan sufficiency with microfinance. To fill up this gap, this study also considered these factors as the independent variables.

\section{Research Framework}

Based on the literature, borrowers can take an interest-free loan from the microfinance institutions. The loan can increase their financial ability to invest more into income generating activities (IGAs). This income ultimately increases their buying ability and to spend more on consumption, thus, leading them to the high quality of living. Therefore, in line with the research objectives, the research framework in Figure 1, illustrate that the indicators of economic impact on borrowers' (household income and consumption expenditures) may affect positively or negatively by the amount of loan, tenure with microfinance institute, training given by microfinance institute, loan sufficiency and borrowers' religiosity.

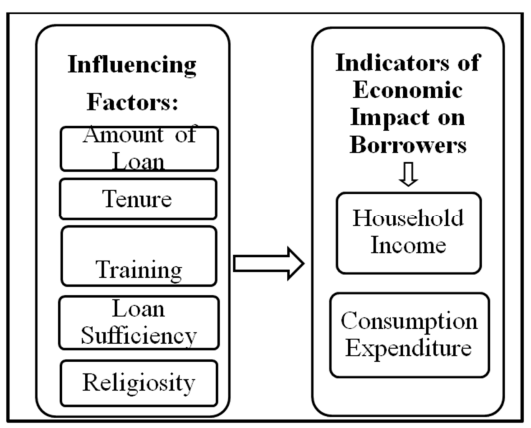

Figure 1. Research framework. 


\section{Data and Methods}

To assess the impacts of MAB microfinance program on rural poor's livelihood, primary data were collected from 95 borrowers from a rural area of Chittagong district, Bangladesh. The survey was undertaken in April 2015. The simple random sampling method was followed to select the borrowers'. Respondents were selected who had been involved in the program for at least three years. The questionnaire design includes five-point Likert scale which was used to explore the borrowers' attitudes towards their income and expenditure under MAB microfinance program.

The study was collected data through interviews. The interviews were face to face with beneficiaries of microfinance institute and focused on the effect of the program on their household income and consumption expenditure. This study followed the explanatory research as a research design. Further, Multiple Linear Regression model were used to see the relationship between chosen factors and income and consumption expenditure.

\section{Results and Discussions}

The impact of microfinance loans on the borrower's household income and expenditures discusses first based on qualitative nature. Qualitative method used to see the improvements after receiving the microfinance loans. Borrowers' improvements was constructed by a set of characteristics of income and expenditure and a preliminary analysis executed to understand the dependent variables (Table 1 and Table 2). The results indicated that a vast majority of borrowers expressed positive attitudes towards MAB microfinance program.

MAB provides a loan to improve the income level of their borrowers through income generating activities. MAB microfinance program had a positive impact on the borrowers' household income. Following Table 1 shows that 94.8\% respondent reported, their household's income increased after they received the loan. Only 5.2\% reported no change. This result indicated that MABs loan helped their borrowers' to raise their income level.

Table 1. Income after joining the MAB program.

\begin{tabular}{lllll}
\hline Variable & Item & Category & Frequency & Percent \\
\hline \multirow{2}{*}{$\begin{array}{l}\text { Household Income } \\
\text { After Joining the } \\
\text { Program }\end{array}$} & $\begin{array}{l}\text { Increased } \\
\text { Monthly }\end{array}$ & $\begin{array}{l}\text { Remain the } \\
\text { Income }\end{array}$ & 50 & 94.8 \\
& & $\begin{array}{l}\text { Decreased } \\
\text { Total }\end{array}$ & - & 5.2 \\
\hline
\end{tabular}

The results of the following Table 2 shows that borrower's expenditures also increased on food, buy clothes, medical treatment, child education, repair \& maintenance respectively $100 \%, 95.8 \%, 97.9 \%, 95.8 \%$ and $95.8 \%$. This result revealed that, MAB program overall increased borrowers' expenditure capability. These findings also indicated that MABs borrower's income and consumption expenditures increased after receiving the microfinance loan.

Table 2. Expenditure after joining the MAB program.

\begin{tabular}{|c|c|c|c|c|}
\hline \multirow{3}{*}{ Variable } & \multirow{3}{*}{ Items } & Increased & Remain the same & Decreased \\
\hline & & $\%$ of $\mathbf{N}$ & $\%$ of $\mathrm{N}$ & $\%$ of $\mathrm{N}$ \\
\hline & & $\mathbf{N}=\mathbf{9 5}$ & $\mathbf{N}=\mathbf{9 5}$ & $\mathbf{N}=95$ \\
\hline \multirow{5}{*}{$\begin{array}{l}\text { Household Consumption Expenditure } \\
\text { After Joining the Program }\end{array}$} & Expenditure on Food & 100 & - & - \\
\hline & Expenditure on clothing & 95.8 & 4.2 & - \\
\hline & Expenditure on Medical Treatment & 97.9 & 2.1 & - \\
\hline & Expenditure on Child Education & 95.8 & 4.2 & - \\
\hline & Expenditure on Repair and Maintenance & 95.8 & 4.2 & - \\
\hline
\end{tabular}

\section{Results of Regression}

Based on the literature, this study identified five factors as the independent variables. The five factors include; the amount of loan, training provided by microfinance institution, tenure with microfinance, loan sufficiency, and religiosity. Then, these five factors tested against income and consumption expenditures which have been adopted as the dependent variables of the study.

\subsection{Regression Results on Household Income}

The following Table 3 shows that all of the variables are reasonable but three of them significantly influences on the household income. The $R^{2}$ was $0.330 \%$ which means that all the variables can explain $33.0 \%$ of the variance in income.

Table 3. Regression results on household income.

\begin{tabular}{lclc}
\hline Variables & Beta & T - Ratio & Sig. t \\
\hline Amount of Loan & .479 & 4.223 & $.000^{*}$ \\
Tenure & .050 & .442 & .659 \\
Training & .023 & .368 & .713 \\
Loan Sufficiency & .165 & 2.654 & $.009^{*}$ \\
Religiosity & .182 & 2.854 & $.005^{*}$ \\
Significant level at $5^{*}$ and $10^{* *}$ percent level; $R^{2}, 0.330$ & \\
\hline
\end{tabular}

Based on the results of the regression analysis shown in Table 3 above, the amount of loan, loan sufficiency and religiosity had the significant effect on income and had a 
positive relationship. Tenure and training were found to have no significant effect on income but found a positive relationship.

\subsection{Regression Results on Borrowers Household Expenditure}

This study assesses the factors of expenditure on household consumption. The possible factors include; the amount of loan, training, tenure, loan sufficiency and religiosity considered to estimate the influence on expenditure. Three of them significantly influences. The $R^{2}$ was 0.316 which means that all the variables can explain $31.6 \%$ of the variance in consumption expenditure.

Table 4. Regression results on consumption expenditure.

\begin{tabular}{llll}
\hline Variables & Beta & T - Ratio & Sig. t \\
\hline Amount of Loan & .677 & 6.035 & $.000^{*}$ \\
Tenure & .210 & 1.859 & $.065^{* *}$ \\
Training & .001 & .002 & .982 \\
Loan Sufficiency & .114 & 1.809 & $.072^{* *}$ \\
Religiosity & .089 & 1.421 & .157 \\
Significant level at $5^{*}$ and $10^{* *}$ percent level; $R^{2}, 0.316$ & \\
\hline
\end{tabular}

Based on the results of the regression analysis shown in Table 4 above, the amount of loan, tenure and loan sufficiency had the significant effect on borrowers' household consumption expenditures and had a positive relationship. Training and religiosity were found to have no significant effect but had a positive relationship.

\section{Conclusion of the Study}

Interest-free Microfinance was introduced in Bangladesh as a part of poverty eradication program. UK-based NGO $\mathrm{MAB}$ first started Interest-free microfinance program in Bangladesh with the following Grameen Bank microcredit model. Therefore, the purpose of this research was to examine the economic impact of that MAB microfinance program on borrower's income and expenditures. MAB has been trying to increase the borrowers' socioeconomic status since its inception. The findings demonstrated that MAB effectively has increased borrowers' household income level and expenditures capacity.

Based on the results, the findings exhibited that "amount of loan", "loan sufficiency" and "religiosity" had the most significant effect on income and had a positive relationship. The result is similar to the study done by [13], [14], [25] and [26]. Factor "tenure" and "Training provided by MAB" did not show the significant result on income. On the other hand, "amount of loan", "tenure" and "loan sufficiency" had the significant effect on consumption expenditure and had a positive relationship. In case of "training" and "religiosity", there was no significant effect on consumption expenditure.

Based on these results and observations, it is found that $\mathrm{MAB}$ training could not effective for the clients. However, the findings revealed that, MAB effectively has increased borrowers' household income and expenditures capacity.

\section{Implications of the Results}

According to the survey of the present study and findings, it has been revealed that income and expenditure are directly related to the amount of loan. Based on this result, Government and NGOs especially MAB should give attention on the size of the loan to improve the level of income. Religious motivation also influenced to the income. Thus, Government and other NGOs should increase the religious motivation for the borrowers. Based on the observation of the borrowers' activities, this study also perceived that there is a misuse of loans occurring among the microfinance borrowers. Monitoring and supervision should be strengthened so that borrowers invest their loan in proper income-generating and welfare activities.

\section{Limitations of the Study}

Despite the useful findings of the study, this study is obviously not without its limitations. This study used the small of respondent and only focus on one area because of time and financial constraint. So, for the future study, the large respondents can be used and compare it with another area such as differentiate between a rural area and urban area.

\section{References}

[1] World Bank (2004), "Building Inclusive Financial Systems" CGAP Report No-35031

[2] Amin, S., Rai, A. S., \& Topa, G. (2003). Does microcredit reach the poor and vulnerable? Evidence from northern Bangladesh. Journal of Development Economics, 70 (1), 5982.

[3] BER, (2012), Bangladesh Economic Review, Economic Adviser's Wing, Finance Division, Ministry of Finance, Government of Peoples Republic of Bangladesh.

[4] UNDP Human Development Report (2011), United Nations Development Program http://hdr.undp.org/en/content/humandevelopment-report

[5] Mahmud, K. T. (2006). Effectiveness of micro-credit for poverty alleviation under Agricultural Intensification Projects in Bangladesh (Doctoral dissertation, Universiti Putra Malaysia).

[6] Credit and Development Forum (CDF) Annual Report. (2014). http://www.cdfbd.org/new/page.php?scat_id=153

[7] MF Report, (2010). Muslim Aid, UK Bangladesh http://www.muslimaid.org.bd/images/stories/pdf/MF_Report_ 2010.pdf

[8] Adnan, M. A., \& Ajija, S. R. (2015). The effectiveness of Baitul Maal wat Tamwil in reducing poverty: the case of Indonesian Islamic Microfinance Institution. Humanomics, 31 (2).

[9] A.M. Inun Jariya (2013). True Economy Prosperity through Poverty Alleviation-Islamic Microfinance as Commercial Venture Proceeding-Kuala Lumpur International Business, Economics and Law Conference. 
[10] Zaidah, N., \& Nor, C. M. (2011). The Effectiveness of Amanah Ikhtiar Malaysia (AIM) in Reducing Rural Poverty: A Case Study of Pokok Sena

[11] Samer, S., Majid, I., Rizal, S., Muhamad, M. R., \& Rashid, N. (2015). The Impact of Microfinance on Poverty Reduction: Empirical Evidence from Malaysian Perspective. ProcediaSocial and Behavioral Sciences, 195, 721-728.

[12] Hamdan, H., Othman, P., \& WSW, H. (2012). Is microfinance program in Malaysia really effective in helping the poor? World Review of Business Research, 2 (1), 79-97.

[13] Md Saad, N., \& Duasa, J. (2010). Determinants of economic performance of micro-credit clients and prospect of Islamic microfinance in Malaysia. ISRA

[14] Rahman, M., \& Ahmad, F. (2010). Impact of microfinance of IBBL on the rural poor's livelihood in Bangladesh: an empirical study. International journal of Islamic and Middle Eastern finance and management, 3 (2), 168-190.

[15] Ahmed, H. (2002). Financing microenterprises: An analytical study of Islamic microfinance institutions. Islamic Economic Studies, 9 (2), 27-64.

[16] Bhuiyan, A. B., \& Hassan, A. (2013). Microcredit and Sustainable Livelihood: An Empirical Study of Islamic and Conventional Credit on the Development of Human Capital of the Borrowers in Bangladesh. Journal of Economic Cooperation and Development, 34 (3), 101-128.

[17] Uddin, M. M. (2008). Credit for the Poor: The Experience of Rural Development Scheme of Islami Bank Bangladesh Ltd. Journal of Nepalese Business Studies, 5 (1), 62-75.

[18] Morshid N, Abdullah R, (2013) The Effectiveness of Islamic Microfinance in Brunei Darussalam: A Case Study Paper presented the $5^{\text {th }}$ Islamic Economic System Conferenceorganized by USM
[19] Widiyanto, M., \& Abdul Ghafar, I. (2010). Improving the effectiveness of Islamic micro-financing. Humanomics, 26 (1), 66-75.

[20] Hassan, A. (2014). The challenge in poverty alleviation:the role of Islamic microfinance and social capital. Humanomics, 30 (1), 76-90.

[21] Khan, Z., \& Usman, M (2010). Financing non Bankable Masses: An Analytical Study of Conventional Verses Islamic Microfinance Programs (Lesson from Muslim World). International Journal of Islamic Finance, 2 (1), 113-130.

[22] Ullah A, Khan Z, \& Yasin H. M (2011). Cooperative Microfinance Myth or Reality: An Economic Analysis of the Welfare of Marginalized Segments. 8th International Conference on Islamic Economics and Finance.

[23] Rahman, M. T., \& Khan, H. T. (2013). The effectiveness of the microcredit programme in Bangladesh. Local Economy, 28 (1), 85-98.

[24] Mawa, B. (2008). Impact of microfinance: towards achieving poverty alleviation? Pakistan Journal of Social Sciences, 5 (9), 876-882.

[25] Chowdhury, T. A., \& Mukhopadhaya, P. (2012). Assessment of multidimensional poverty and effectiveness of microfinance-driven government and NGO projects in the rural Bangladesh. The Journal of Socio-Economics, 41 (5), 500-512.

[26] Rulindo, R., \& Pramanik, A. H. (2013). Finding a Way to Enhance Impact of Islamic Microfinance: The Role of Spiritual and Religious Enhancement Programmes. Developing Country Studies, 3 (7), 41-52. 